\title{
Tek hücre jel elektroforezi yöntemi için alternatif güvenli boyalar
}

\author{
Alternative safe stains for single cell gel electrophoresis assay \\ Sibel Ünlü*, Emel Sağlar \\ Moleküler Biyoloji Anabilim Dalı (Dr. S. Ünlü, Dr. E. Sağlar), Hacettepe Üniversitesi Fen \\ Fakültesi, TR-06800 Ankara
}

\section{Özet}

Amaç. Tek hücre jel elektroforezi veya yaygın olarak kullanılan diğer adı ile Comet Assay tekniği DNA hasarını belirlemek için kullanılan hassas, hızlı ve ucuz bir sitogenetik yöntemdir. Temel olarak bu metod hücrelerin mikroskop lamı üzerinde agaroz içine gömülüp, lizizi sonrası elektroforeze tabi tutularak floresan boyalar ile boyanması ardından DNA'daki hasarın görüntülenmesine dayanmaktadır. Görüntüleme aşamasında interkalatör boyalar olan etidyum bromür ve propidyum iyodit yaygın olarak kullanılmaktadır. Ancak bu boyalar mutajenik ve olası karsinojenik özelliklerinden dolayı kullanım aşamasında oldukça dikkat gerektirmektedir. $\mathrm{Bu}$ çalışmada DNA'nın tek hücre jel elektroforezinde görüntülenebilmesi için alternatif olabilecek iki karsinojenik olmayan güvenli boyanın kullanılabilirliği araştııılmıştır. Sağlıklı ve gönüllü bir bireyden alınan periferal kan örneğinden ayrıştırılan lenfositler hücre kültüründe çoğaltılmış, kültür örneği ikiye ayrılarak biri kontrol olarak kullanılmış, diğeri $0,527 \mathrm{kGy} / \mathrm{h}$ doz hızlı ${ }^{137} \mathrm{Cs}$ kaynağında 2 Gy ışınlanmıştır. Kontrol ve ışınlanmış örneklere alkalin comet assay yöntemi uygulandıktan sonra lamlar hem etidyum bromür ve propidyum iyodit ile hem de alternatif olarak SafeView ve GelStar boyaları ile boyanmıştır. Bulgular. Elde edilen veriler, klasik boyalarla karşılaştırıldığında bu iki alternatif boyanın son derece etkin çalıştı̆̆ını göstermiştir. Sonuç. $\mathrm{Bu}$ çalışma sonucunda klasik agaroz jel elektroforezi yönteminde DNA ve RNA'yı görüntülemek amaçlı kullanılan SafeView ve GelStar boyalarının, literatürde ilk kez tek hücre jel elektroforezi yönteminde DNA'yı görüntülemek için hassas ve etkin şekilde kullanılabildiği gösterilmiştir.

Anahtar sözcükler: Comet assay, DNA hasarı, floresan boyalar

\begin{abstract}
Aim. Single cell gel electrophoresis or the other common name Comet assay technique is a sensitive, fast and cheap cytogenetic method for DNA damage assessment. Method consists of embedding cells to the agarose on microscope slides, electrophoresis following lysis and staining with fluorescent dyes for DNA damage visualization basically. At the staining stage intercalator dyes ethidium bromide and propidium iodide are used widely. However because of the mutagenic and possible carcinogenic properties of these dyes, they must be used very carefully. Method. In this study applicability of two safe non-carcinogenic dyes for DNA visualization in single cell gel electrophoresis is investigated. Lymphocytes from blood sample of a healthy volunteer donor were separated and propagated in cell culture, divided into two, one of them used as control and the other is irradiated $2 \mathrm{~Gy}$ at a $0,527 \mathrm{kGy} / \mathrm{h}$ dose rated ${ }^{137} \mathrm{Cs}$ source. Alkaline comet assay was applied and slides were stained with ethidium bromide and propidium iodide also with alternative SafeView and GelStar dyes. Results. Optained data shows that, when compared with the conventional ones these two alternative dyes worked efficiently. Conclusion. Results of this study showed that SafeView and GelStar dyes which are used in classical agarose gel electrophoresis method for DNA and RNA staining, can also be used efficiently in single cell gel electrophoresis for the first time in literature.
\end{abstract}

Keywords: Comet assay, DNA damage, fluorescent dyes

Geliş tarihi/Received: 19 Temmuz 2012; Kabul tarihi/Accepted: 30 Kasım 2012

\section{*İletişim adresi:}

Dr. Sibel Ünlü, Moleküler Biyoloji Anabilim Dalı, Hacettepe Üniversitesi Fen Fakültesi, Beytepe Kampüsü, 06800, Ankara. E-Posta: unlusibel@gmail.com 


\section{Giriş}

Tek hücre jel elektroforezi DNA hasarlarının ve onarımının tespitine tek aşamada izin veren bir yöntemdir [1]. Bu teknik tek hücrenin agaroza yerleştirilmesini takip eden hücre lizizi, elektroforez, mikroskopta inceleme ve görüntüleme yoluyla analizinden oluşmaktadır. Hücrelerin mikroskopta kuyruklu yıldız görünümünde olmasından dolayı Comet Assay olarak da adlandırılmaktadır. Comet parametrelerini ve analizini kolaylaştırmak için yazılımlar geliştirilmiştir [2]. DNA tek ve çift zincir kırıklarının, alkali-kararsız bölgelerinin ve eksik kesip çıkarma onarım bölgelerinin ve zincir içi çapraz bağların tespiti için Comet Assay yönteminde değişiklikler yoluyla yeni teknikler geliştirilmiştir. Tek hücre jel elektroforez tekniği DNA hasarının tespiti için yaygın olarak kullanılmaya başlayan bir metod haline gelmektedir. Gelişimi Rydberg ve Johanson'un [3] agaroz ile ışınlanmış Çin hamster hücrelerini karıştırarak alkali bir çözeltide lizize uğratıktan sonra akridin oranj ile boyayıp DNA zincir ayrışmasının uzayışını gözlemlemesiyle başlamıştır. Daha sonra, Ostling ve Johanson [4] tarafından, hücrelerin nötral bir deterjan çözeltisinde lizize uğratılması ve akridin orange ile floresans değerlendirmeden önce hücrelere düşük bir elektriksel alan uygulanmas1 ile bu metod modifiye edilmiştir. Günümüzde Comet Assay'in kabul gören iki şekli vardır, biri Singh ve arkadaşları [5] tarafından, diğeri ise Olive ve arkadaşları [6] tarafından geliştirilmiştir. Geliştirilen versiyonlar prensipte aynı olmakla beraber, ana faklılık elektroforezin pH'sindadır. Singh'in metodu elektroforezin $\mathrm{pH}>13$ 'de yapılmasını gerektirmektedir ve bundan dolayı Alkalin Comet Assay olarak adlandırılır. Aksine, Olive'in [6] metodu elektroforezin $\mathrm{pH}$ 8,3'te yapılmasını içermektedir, bu nedenle de nötral elektroforez olarak adlandırılır. Her iki metodda tek zincir ve çift zincir kırıklarını tespit edebilirken, alkali yöntem aynı zamanda alkali değişime eğilimli bölgeleri de tespit edebilmektedir [7]. Bu nedenle alkalin yöntem daha yaygın kullanılmaktadır. Alkalin Comet Assay'in temel basamakları şunlardır: Tek hücre süspansiyonu elde etmek, mikroskop lamlarının hazırlanmas1, hücre lizizi, enzim ile muamele (opsiyonel), alkali yoluyla gevşetme (yüksek alkali DNA çift zincirinde karşılıklı gelen bazlar arasındaki hidrojen bağlarını kırar, bu da zincir kırığının meydana geldiği yerden DNA çift zincirinin gevşemesine ve DNA fragmentlerinin oluşmasına yol açar), elektroforez, nötralizasyon ve "comet"in görüntülenebilmesi için DNA'nın boyanması. Deney sonunda hücrelerin değerlendirilmesinde çeşitli görüntüleme analiz programlarından yararlanılır. Deney, hücre düzeyindeki DNA hasarını ölçme esasına dayanmaktadır. DNA hasarına uğramış hücre, kafa ve kuyruk olarak iki kısımdan meydana gelmiştir. "Kafa" bölgesi çekirdek dışına göç etmeyen, "kuyruk" ise parçalanmaya ve yapısal kayba bağlı olarak çekirdek dışına göç etmiş DNA'yı belirtir. Belli bir bölgedeki DNA miktarı o bölgedeki floresans yoğunluğu ile doğru orantılıdır. Bu özellikten yararlanarak dijital görüntü sistemlerinde ve analiz yazılım programlarındaki ilerlemeye paralel olarak daha hassas ve doğru sonuç veren miktar tayin yöntemleri geliştirilmiştir. 1990 yllından itibaren kuyruk momentinin hesabı kafa hücresinin merkezinden kuyruğun kütlesel merkezine uzaklığının kuyruktaki DNA fraksiyonu ile çarpımına dayanmaktadır. Kısacası kuyruk momenti hesaplanırken sadece kuyruktaki DNA miktarı değil göç ettiği mesafe de dikkate alınmaktadır [8]. Comet assay, DNA hasarına olan duyarlılığı, gereken örnek miktarı ve maliyetinin düşük olması açısından avantajlı bir yöntemdir. Genotoksisite, DNA onarım çalışmaları, çevresel ve insan biyoizleme (biomonitoring) çalışmaları ve klinik çalışmalara kadar geniş bir yelpazede uygulama alanı vardır. Comet Assay'i kullanan genotoksisite çalışmaları çeşitli metaller, pestisitler, nitroaminler ve antineoplastik ilaçlar üzerinde yapılmıştır [7]. Yöntem çoğunlukla hangi maddelerin tek veya çift zincir kırıklarına yol açtığını araştırmak için kullanılmıştır. Fakat aynı zamanda, çeşitli tipte hasarlı bazları tanıyan özgül endonükleazların kullanımı ile hasarın mekanizması hakkında da yararlı bilgiler sağlayabilir. Aynı zamanda, test gruplarından birine dolaylı bir karsinojeni, onun aktif formuna dönüştürebilen enzimleri içeren bir S9 fraksiyonunun eklenmesiyle, bir maddenin pro veya dolaysız bir karsinojen olduğunu belirlemede de yararlı bilgiler sağlayabilir. Comet Assay aynı zamanda bir test maddesinin kemoprotektif özelliklerini, 
örneğin, antioksidanların $\mathrm{H}_{2} \mathrm{O}_{2}$ tarafından oluşturulan oksidatif etkilerini azaltma yeteneklerini belirlemede de kullanılabilir. DNA hasarına ek olarak, bilinen bir DNA'ya hasar veren ajana maruz bırakılan bir hücre populasyonunda, onarım çalışmaları da yapılmıştır. Bu amaçla, hücrelerde oluşan DNA hasarı kontrol seviyelerine dönene kadar, çeşitli zaman aralıklarında Comet Assay analizleri yapılmıştır [9]. Onarım sürecinin kinetiği, onarım inhibitörleri, DNA sentez inhibitörleri veya zincir sonlandırıcıları (zincir uzamasını engelleyen nükleik asit analogları) kullanılarak incelenebilir [10]. Comet Assay'in aynı zamanda çevresel biyoizlemede de yararlı olduğu gösterilmiştir. Biyoizleme çalışmaları, kirlenmiş göllerden toplanan balıkların beyaz kan hücrelerinin [11], farklı toprak örneklerinden solucanların sölom hücrelerinin [12] ve tehlikeli atık bölgelerinde yaşayan kemirgenlerden dokuların örneklenmesi ile gerçekleştirilmiştir [7, 13]. Aynı şekilde Comet Assay insanların biyoizlenmesinde kullanılmıştır. Örneğin, DNA'ya hasar veren ajanlara mesleki olarak maruz kaldığından şüphelenilen bireylerin kan örneklerinde [14] veya hava kirliliği olan şehirlerde yaşayan insanların nazal epitelyum hücrelerinde [15] Comet Assay uygulanmıştır.

Literatürde belirtildiği gibi çok çeşitli uygulama alanlarına sahip olan bu yöntem, DNA hasarını hızlı ve kesin şekilde belirleyebildiği için sitogenetik çalışmalarda artan şekilde kullanılmaktadır.

Tek hücre jel elektroforezi yönteminde DNA'yı görüntüleyebilmek için çok çeşitli boyalar kullanılmaktadır. Bunlardan en yaygın olarak kullanılanlar Etidyum bromür ve propidyum iyodit'dir. Etidyum bromür interkalatör bir boyadır. Pozitif yüklü polisiklik aromatik bir bileşik olup, DNA'ya baz çiftlerinin arasına yerleşerek bağlanmaktadır. Bağlanma DNA sarmalının yaklaşık $26^{\circ}$ 'lik bölgesel açılmasına neden olarak molekülün negatif kıvrımında azalmaya neden olur [16]. Propidyum iyodid (PI) 488 nm'de kırmızı floresans yayan interkalatör bir boyadır. PI nükleik asitlere bağlandığında, floresans eksitasyon maksimumu $532 \mathrm{~nm}$ ve emisyon maksimumu 617 nm'dir. DNA'ya baz seçmeden veya çok az seçici olarak 4-5 baz başına bir molekül şeklinde bir stokiyometri ile bağlanır [17]. Bu boya moleküllerinin bağlanması ile DNA yapısında meydana gelen konformasyonel değişimler ve boya moleküllerinin baz çiftleri arasına yerleşmesi DNA'nın replikasyonuna ve transkripsiyona engel olur.

Bu çalışmada tek hücre jel elektroforezinde tek ve çift zincirli DNA'nın görüntülenmesi için yaygın olarak kullanılan ancak mutajen ve olası karsinojen özellikleri olan etidyum bromür ve propidyum iyodid boyalarına alternatif olabilecek karsinojenik olmayan SafeView (NBS Biologicals Ltd) ve GelStar (Lonza) boyalarının kullanımı araştırılmıştır.

\section{Gereç ve yöntem}

Sağlıklı ve gönüllü bir bireyden Lityum-heparinli tüpe alınan kan örneğinden lenfositler Histopaque-1077 kullanılarak ayrıştırılmıştır. Lenfositler RPMI 1640 besiyeri (\%10 FBS, $\% 1$ pen/strep) kullanılarak \%5'lik $\mathrm{CO}_{2}, \% 95$ hava koşulu altında kültür ortamında çoğaltılmıştır. Hücre kültürü ikiye ayrılıp, kültürün biri $0,527 \mathrm{kGy} / \mathrm{h}$ doz hızlı Cs137 kaynağında 2 Gy ışınlanmıştır, diğeri kontrol olarak kullanılmıştır. Besiyeri santrifüj ile uzaklaştırılarak elde edilen hücre süspansiyonunun $20 \mu$ l'si $80 \mu 1 \% 0,8$ 'lik düşük erime noktalı agaroz ile karıştırılıp \%2'lik normal erime noktalı agaroz ile kaplanmış lamın ortasına damlatılmış ve üzeri lamel ile kapatılıp buz üzerinde 10 dakika bekletilmiştir. 10 dakika sonunda lamel dikkatlice çekilerek çıkartılmış ve lamın üzerine $80 \mu 1$ düşük erime noktalı agarozdan damlatılıp tekrar lamel ile kapatılarak 10 dakika daha buz üzerinde bekletilmiştir. Süre sonunda lamel dikkatlice çekilip çıkartılarak lamlar taze hazırlanan liziz çözeltisinde $(2,5 \mathrm{M} \mathrm{NaOH}, 100 \mathrm{mM}$ EDTA, $10 \mathrm{mM}$ Trizma base hazırlanır ve taze olarak $1 \%$ Triton X-100 and 10\% DMSO kullanımdan önce eklenir) karanlıkta $+4^{\circ} \mathrm{C}$ 'de 1 saat bekletilmiştir. Lizizden çıkartılan lamlar elektroforez tankına yerleştirilip, elektroforez çözeltisi ( $300 \mathrm{mM} \mathrm{NaOH}, 1 \mathrm{mM} \mathrm{Na}$ EDTA, pH 13,0) içerisinde 30 dakika bekletilmiştir. Süre sonunda $25 \mathrm{~V}$ (volt), $300 \mathrm{~mA}$ (miliamper)'de 30 dakika yürütülmüştür. Elektroforez sonunda preparatlar $3 \mathrm{kez} 5$ 'er dakika nötralizasyon tamponu (0,4 M Tris, 
pH 7,5) ile yıkanmıştır. Lamlar oda 1 sısında gece boyu veya $50^{\circ} \mathrm{C}^{\prime}$ de 1 saat kurutulmuştur. DNA'yı görüntülemek için lamlar $0,1 \mathrm{M} \mathrm{NaCl}$ içerisinde çözünmüş 2,5 $\mu \mathrm{g} / \mathrm{mL}$ propidyum iyodit veya suda çözünmüş $2 \mu \mathrm{g} / \mathrm{mL}$ etidyum bromür ile 15 dakika boyanmıştır. Aynı zamanda bu boyalara alternatif olarak kanserojen olmayan SafeView (NBS Biologicals Ltd) ve GelStar (Lonza) boyaları kullanılmıştır. Stok boyadan 7,5 $\mu 1$ alınıp $650 \mu$ l'ye TE (10mM TRİS, 1mM EDTA; pH 7,6) tamponu ile tamamlanıp ve lam başına bu karışımdan $65 \mu \mathrm{l}$ eklenerek üzerleri 24x60'lık lameller ile kapatılmış ve 450$490 \mathrm{~nm}$ eksitasyon ve $510 \mathrm{~nm}$ bariyer filtreli Leica marka floresan mikroskobunda 40x objektifte incelenmiştir. Analiz sonucunda etidyum bromür ve propidyum iyodit gibi SafeView ve GelStar boyalarınında etkin şekilde DNA'yı boyayarak floresans mikroskopta görüntülemey izin verdiği tespit edilmiştir.

\section{Bulgular}

Analiz sonunda lenfosit hücrelerindeki DNA'nın etidyum bromür, propidyum iyodit ve alernatif boyalar olan SafeView ve GelStar ile boyanmış görüntüleri Şekil 1'de yer almaktadır. Klasik boyalarla karşılaştırıldığında bu iki alternatif boyanın son derece etkin çalıştı̆̆1 görülmüştür.

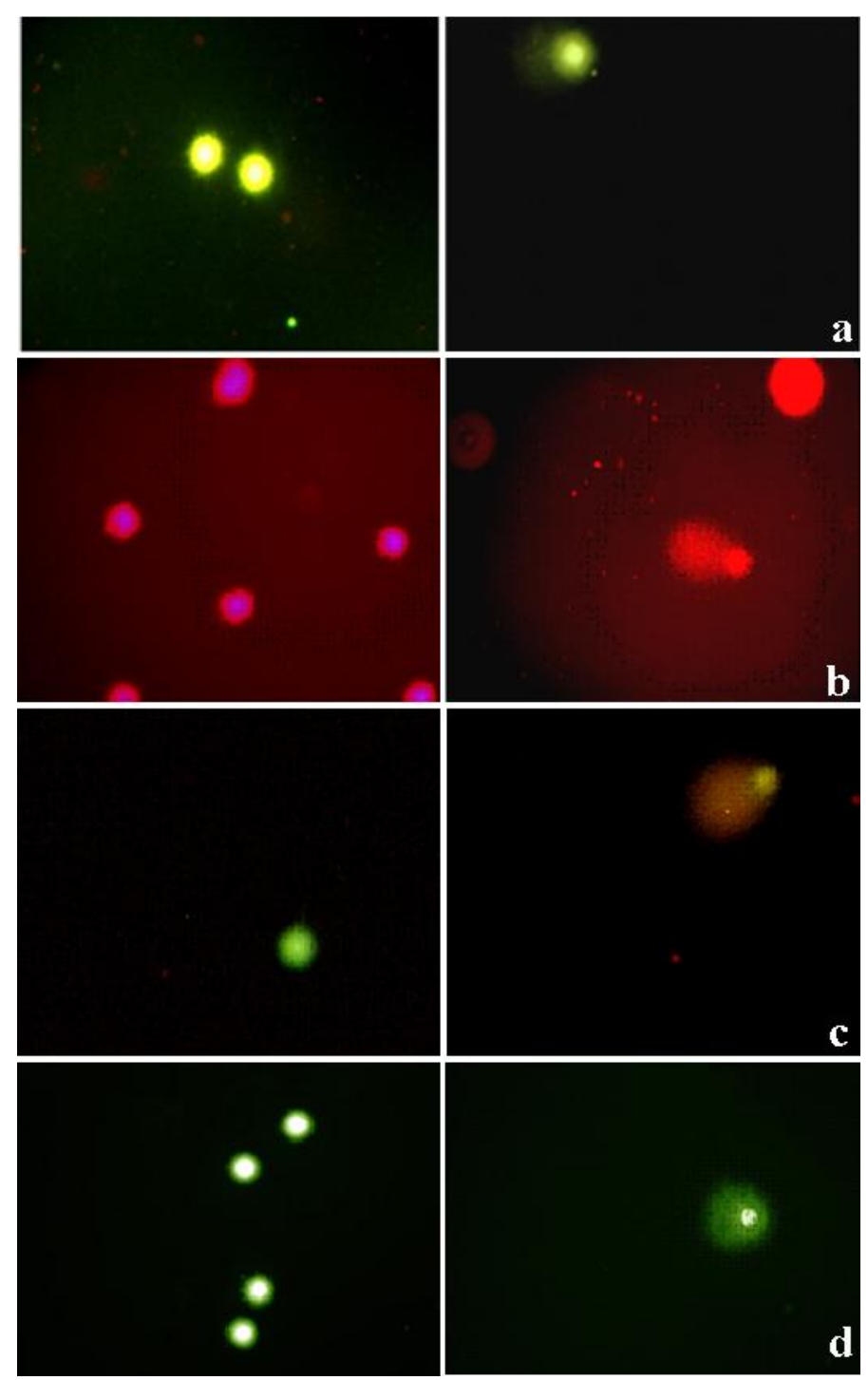

Şekil 1. Kontrol (sol tarafta) ve 2 Gy’de ışınlanmış (sağ tarafta) lenfosit hücrelerinin alkalin comet assay sonrası (A) Propidyum iyodid, (B) Etiyum bromid, (C) SafeView ve (D) GelStar boyaları ile boyandıktan sonraki görüntüleri. 


\section{Tartışma}

SafeView agaroz jelde çift zincirli ve tek zincirli DNA ve RNA'y1 görüntülemek için geliştirilmiş bir boyadır. Çift zincirli DNA'ya bağlandığında yeşil, tek zincirli DNA ve RNA'ya bağlandığında da kırmızı floresans yayar. Floresans eksitasyon maksimumu yaklaşı 290-330nm'de, 515nm emisyondadır. Karsinojenik değildir ve Ames-testinde önemli ölçüde daha düşük mutasyonlara yol açar ve fare kemik iliği eritrosit testi ve fare spermatosit kromozomal aberasyon testlerinde negatif sonuç vermektedir. GelStar nükleik asitleri agaroz jel ve poliakrilamid jelde görüntülemek için geliştirilmiş oldukça hassas bir boyadır. Çift-zincirli veya tek-incirli DNA veya RNA'nın dedeksiyonunda oldukça yüksek hassasiyete sahiptir. Etidyum bromür ile karşılaştırıldığında agaroz jelde çift zincirli DNA'yı görüntülemede 4-16 kat, tek zincirli DNA'y1 görüntülemede ise 2080 kat artmış hassasiyettedir. Floresans eksitasyon maksimumu $493 \mathrm{~nm}$ 'de, $527 \mathrm{~nm}$ emisyondadır, RNA için $532 \mathrm{~nm}$ 'dir. Diğer boyaların aksine Tris-EDTA tampon ile sulandırılarak hazırlandığında dayanma ve solma süresi çok daha uzundur. Tek hücre jel elektroforezi veya diğer adı ile Comet Assay DNA hasarını ölçmek için kullanılan hızlı, hassas ve ucuz bir test tekniğidir. Yöntemin uygulanmasının ardından DNA'yı görüntüleyebilmek için kullanılan çok çeşitli boya alternatifi mevcuttur. Ancak bunların pek çoğu mutajen ve olası karsinojenler olup hazırlanma, kullanma ve atık yönetimi aşamalarında oldukça dikkat isteyen boyalardır. $\mathrm{Bu}$ nedenle bu boyalara alternatif olabilecek yeni nesil karsinojenik olmayan çok daha güvenli boyaların kullanılabilirliği araştırılmıştır. Bu boyalar kullanıma hazır sıvı formda geldiği için, ayrıca Etidyum bromür ve propidyum iyodit gibi toz şeklinde olmadıkları için yüzeysel kontaminasyon riski düşük olup, inhalasyon yolu ile kontaminasyon riski yoktur. Yalnızca kullanım öncesi stok çözeltiden seyreltme yapılarak kullanıma hazır hale gelmektedir. Ayrıca TE gibi $\mathrm{pH}$ değeri 7 ila 8,5 olan bir çözelti ile sulandırıldığında Comet Assay görüntülemesinde yaşanan en büyük problemlerden biri olan boyanın floresan mikroskopta çalışırken cıva lambası etkisi ile solması probleminin de büyük ölçüde üstesinden gelmek mümkün olmaktadır. SafeView'in tek zincirli ve çift zincirli DNA'ya bağlandığında farklı renkte floresans 1şıması gerekli durumlarda ikisini tek boya kullanarak birbirlerinden ayırt etmeyi olası kılmaktadır. Ayrıca GelStar'ın çok daha yüksek hassasiyete sahip olması nedeni ile analiz sonuçlarının doğruluğunu arttırmak mümkün olmuştur. Bu çalışma ile tek hücre jel elektroforezi yönteminde daha önceden kullanılmamış olan iki alternatif, güvenli boyanın etkin şekilde kullanılabileceği gösterilmiştir.

\section{Kaynaklar}

1. Olive PL. Impact of the comet assay in radiobiology. Mutat Res 2009; 681: 1323.

2. Verde PE, Geracitano LA, Amado LL, Rosa CE, Bianchini A, Monserrat JM. Application of public-domain statistical analysis software for evaluation and comparison of comet assay data. Mutat Res 2006; 604: 71-82.

3. Rydberg B, Johanson KJ. Estimation of DNA strand breaks in single mammalian cells. DNA Repair Mechanism (Hanwalt PC, and Friedberg, EC. Eds), Academic Press, New York 1978; 465-8.

4. Ostling O, Johanson KJ. Microelectrophoretic study of radiation-induced DNA damages in individual mammalian cells. Biochem Biophys Res Commun 1984; 123: 291-8.

5. Singh NP, McCoy MT, Tice RR, Schneider EL. A simple technique for quantitation of low levels of DNA damage in individual cells. Exp Cell Res 1988; 175: 184-91.

6. Olive PL, Banáth JP, Durand RE. Heterogeneity in radiation-induced DNA damage and repair in tumor and normal cells measured using the "comet" assay. Radiation Research 1990; 122: 86-94.

7. Rojas E, Lopez MC, Valverde M. Single cell gel electrophoresis assay: 
methodology and applications. J Chromatogr B Biomed Sci Appl 1999; 722: 22554.

8. Başaran A. Farmakognozide Tek Hücre Jel Elektroforezi Uygulamaları. 14. Bitkisel İlaç Hammaddeleri Toplantısı, Bildiriler, 29-31 Mayıs 2002, Eskişehir, 2002

9. Singh NP, Danner DB, Tice RR, Brant L, Schneider EL. DNA damage and repair with age in individual human lymphocytes. Mutation Research 1990; 237: 12330 .

10. Gedik CM, Ewen SW, Collins AR. Single-cell gel electrophoresis applied to the analysis of UV-C damage and its repair in human cells. Int J Radiat Biol 1992; 62: 313-20.

11. Ralph S, Petras M. Genotoxicity monitoring of small bodies of water using two species of tadpoles and the alkaline single cell gel (comet) assay. Environmental and Molecular Mutagenesis 1997; 29: 418-30.

12. Salagovic J, Gilles J, Verschaeve L, Kalina I. The comet assay for the detection of genotoxic damage in the earthworms: a promising tool for assessing the biological hazards of polluted sites. Folia Biol (Praha) 1996; 42: 17-21.

13. Verschaeve L, Gilles J. Single cell gel electrophoresis assay in the earthworm for the detection of genotoxic compounds in soils. Bull Environ Contam Toxicol. 1995; 54: 112-9.

14. Somorovská M, Szabová E, Vodicka P, Tulinská J, Barancoková M, Fábry R, Lísková A, Riegerová Z, Petrovská $\mathrm{H}$, Kubová J, Rausová K, Dusinská M, Collins A. Biomonitoring of genotoxic risk in workers in a rubber factory: comparison of the comet assay with cytogenetic methods and immunology. Mutat Res 1999; 445: 181-92.

15. Calderón-Garcidueñas L, Osnaya N, Rodríguez-Alcaraz A, Villarreal-Calderón A. DNA damage in nasal respiratory epithelium from children exposed to urban pollution. Environ Mol Mutagen 1997; 30: 11-20.

16. Turner PC, McLennan AG, Bates AD. Instant notes in Molecular Biology. 3 rd ed. New York: Taylor \& Francis, 2005; pp: 49.

17. Suzuki T, Fujikura K, Higashiyama T, Takata K. DNA staining for fluorescence and laser confocal microscopy. J Histochem Cytochem 1997; 45: 49-53. 